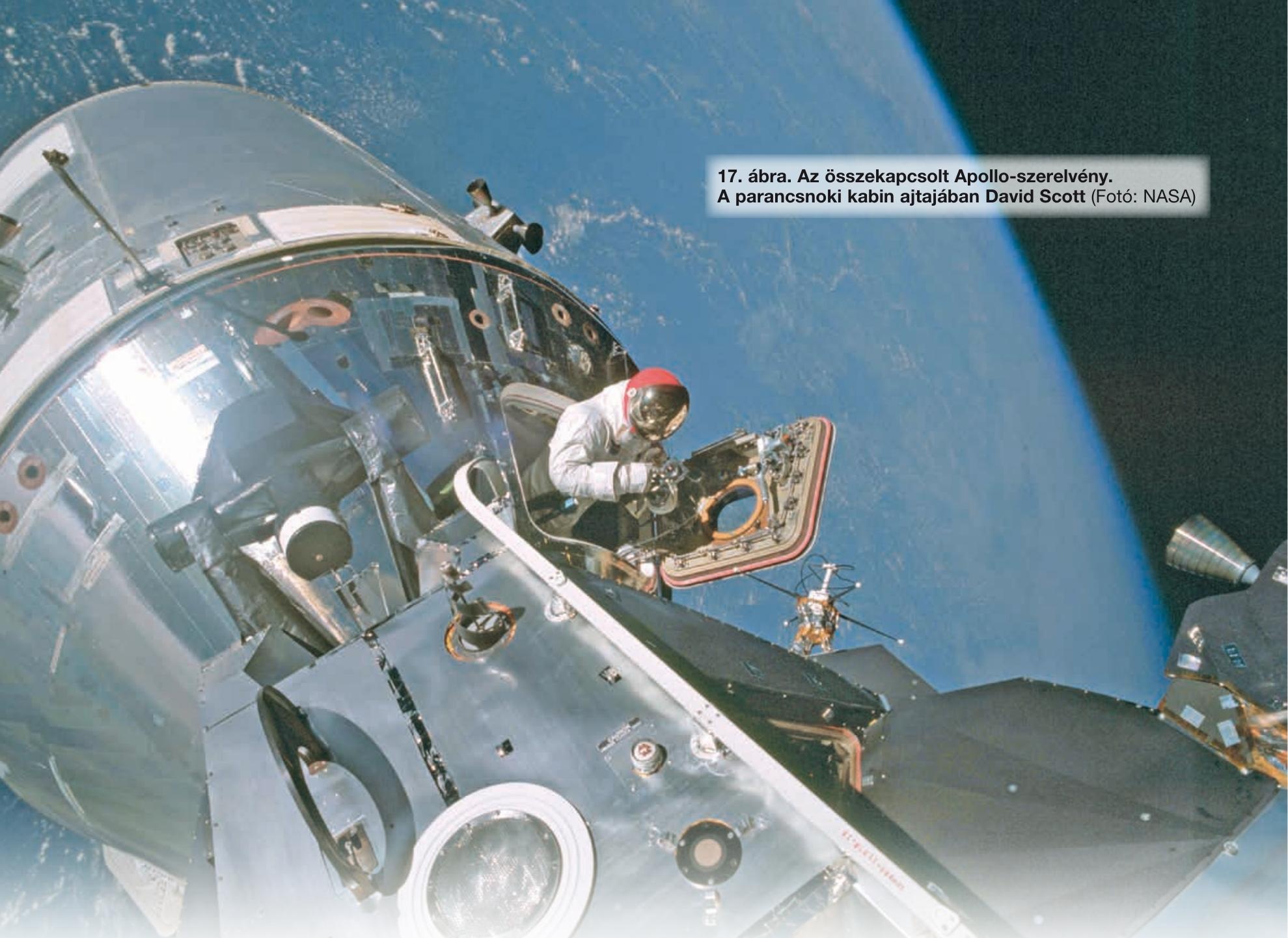

Schuminszky Nándor*

\title{
Verseny a Holdért. Az Apollo program - 50 év után urresz
}

\section{Karnyújtásnyira a céltól}

$$
1
$$

965 decemberében, a sikeres Gemini-7 és -6 ürrandevúja után a legtapasztaltabb ürhajósokat - Virgil Grissom, James McDivitt, Edward White, Walter Schirra és Frank Borman - átirányították az Apollo-programba, hogy megkezdjék a tényleges felkészülést a holdutazásra. 1966. március 21 -én bejelentették az első, szeptember 29-én a második, és december 22-én a harmadik Apollo személyzetének összetételét és feladatát, de az 1967. január 27-én bekövetkezett Apollo-1 katasztrófája felborította az eredeti terveket, és azok csak a később, az Apollo-1 az Apollo-7, az Apollo-2 az Apollo-9 és az Apollo-3 az Apollo-8 programjában valósultak meg.

Az átalakított úrhajót Apollo-4 néven, mintegy 10 hónappal a szerencsétlenség után, 1967. november 9-én indították. A Saturn-V rakéta első próbáján az ürhajó mintegy 18 ezer km-re távolodott el a Földtől, ezért megközelító módon szimulálhatták a Holdtól visszatérő üreszköz pályáját, amin megközelíti, vagy akár el is érheti a második kozmikus sebesség értékét. A visszatérés során a szükséges sebesség-csökkentéshez az aerodinamikai fékezési módszert is kipróbálták. Meghatározott magasságon vezették be a Föld légkörébe, és az ott fellépő légellenállás segítségével csökkentették az Apollo-4 ürkabinjának sebességét, hogy kisebb mennyiségủ hajtóanyag felhasználásával hajtsák végre a fékezést.

A NASA tervei szerint még két holdkomppróba és egy újabb Saturn-V repülés előzte volna meg az első Apollo ürhajó pilótás berepülését. A kis lépésekkel megvalósítandó terv szerint ezek után kerülhetett volna sor a komplett Apollo űrhajórendszer Föld körüli repülésére.

1968 januárjában a holdkomp (Apollo-5) működését még ürhajósok nélkül próbálták ki. Az utolsó - személyzet

\footnotetext{
Magyar Asztronautikai Társaság ORCID: 0000-0001-7947-8645
} 


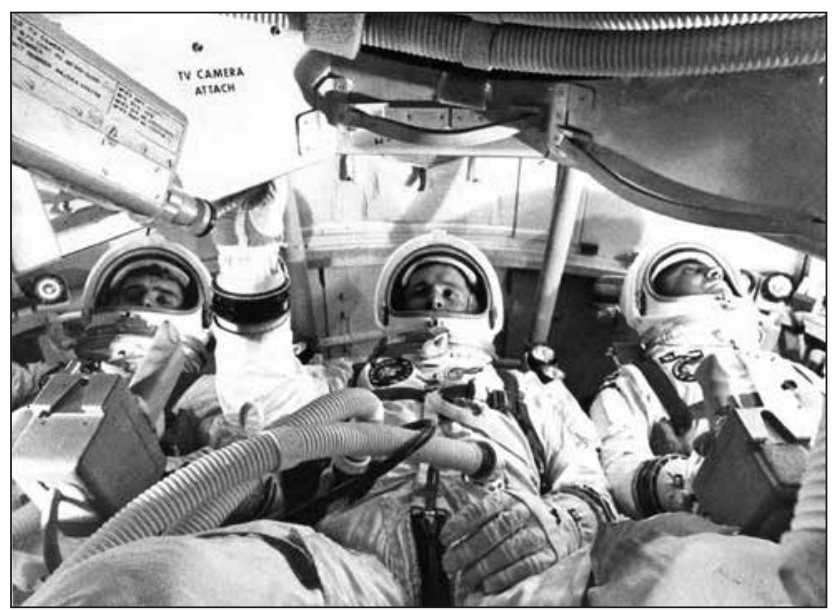

18. ábra. Ennél a kísérletnél a levegőt még külső ellátással biztosították a személyzet számára. Jobbról: V. Grissom, E. White, R. Chaffee (Fotó: NASA)

nélküli - Apollo kísérletre 1968 áprilisában került sor. Már az emelkedés alatt hiba lépett fel; a Saturn- $V$ rakéta második fokozatának öt hajtóműve közül kettő, kb. 1 perccel korábban leállt a többinél. Ezért a második, majd a harmadik fokozatnak is tovább kellett müködnie, de az Apollo-6 így sem érte el a tervezett magasságot. A Service Modul egyetlen J-2-es hajtóművével sikerült a „pótlás”, és visszatérésekor az űrkabin $64 \mathrm{~m} / \mathrm{s}$ sebességtöbblettel lépett be a légkörbe, ezért a keletkező hő is $8 \%$-kal lett több a tervezettnél. A hővédőpajzs azonban kiállta a próbát, és egy kisebb irányítástechnikai nehézség ellenére az Apollo-6 sikeresen leszállt a Csendes-óceánra.

1968 késő nyarára egyre nagyobb nyomás nehezedett a NASA-ra, mert sorban érkeztek a felderítési adatok a CIAtől, és egy memorandumban Lyndon B. Johnson elnök is tájékoztatást kapott egy közeljövőben esedékes szovjet holdkerülő repülésről, valamint a tervezett Holdra szállásról. A szovjet elsőségtől való félelem drasztikus lépésre sarkallta a NASA-t. Lemondtak a második holdkomp pró-

19. ábra. Az ürkabin külső burkolatán is jól láthatók a hatalmas tứz nyomai (Fotó: NASA)

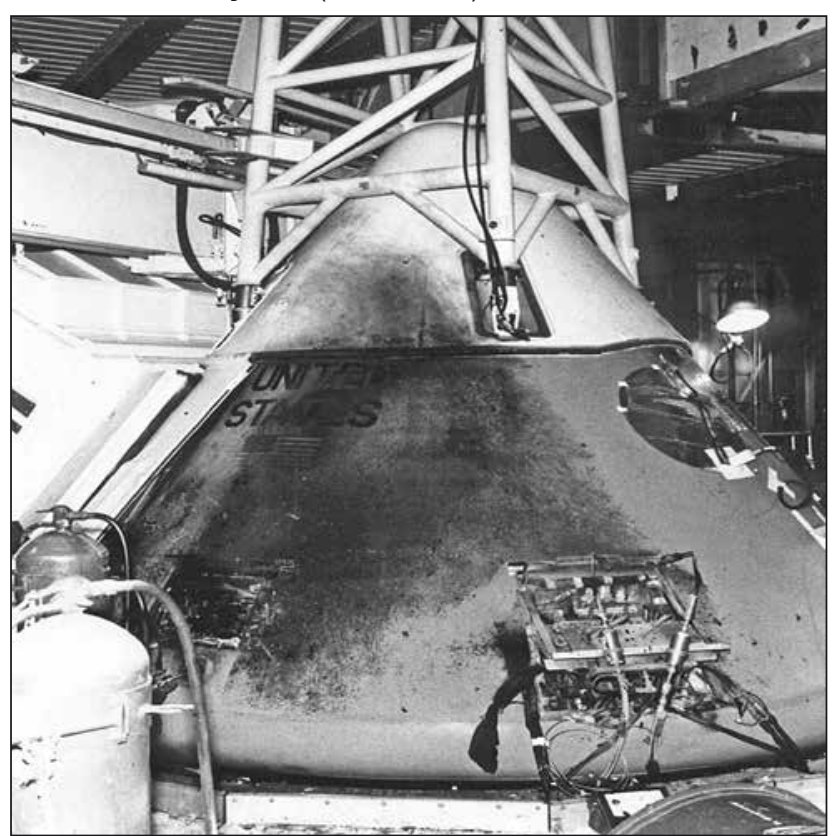

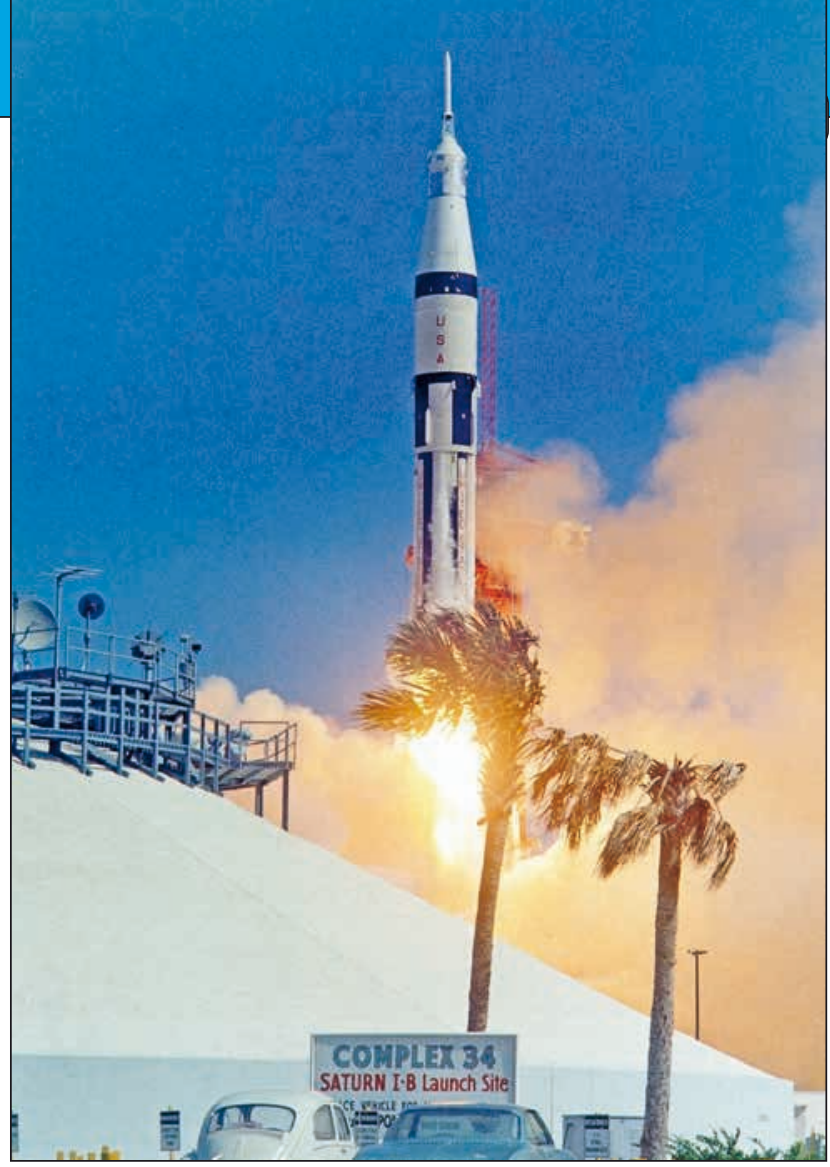

20. ábra. Emelkedik az Apollo-7 (Fotó: NASA)

bájáról, és a Saturn-V-Apollo pilótás berepüléséről Föld körüli pályán. Előbbre hozták a komplett Apollo-űrhajórendszer próbáját bolygónk körül, majd a következő kísérletben ezt ismételték volna meg, de már a Hold körüli pályán.

A NASA - a második Saturn-V-nél fellépő problémák ellenére, de nem utolsó sorban az idő sürgetése miatt engedélyezte az első pilótás repülést, igaz, csak a SaturnIB-vel.

Az Apollo-7 1968. október 11-én startolt, és a több mint 10 napos utazás folyamán 163 alkalommal kerülte meg a Földet. Az űrhajósok különféle manővereket, valamint űrrandevú jellegű megközelítéseket végeztek az S-IVB fokozattal, és ellenőrizték az űrhajó műszaki rendszereit, műszereit és egyéb berendezéseit.

\section{Megvalósult Verne Álma}

A kívánalmak azonban még az Egyesült Államokban is nagyobbak voltak a lehetőségeknél. Az AS-504-es, kísérletre előirányzott holdkompot hiába szerették volna már 1968 decemberében az Apollo-8 (AS-503-as) repülésénél felhasználni, ez vágyálomnak bizonyult. Mai szemmel nézve kritikus döntést hoztak, amely csak az elsőség mindenáron való megszerzésével magyarázható. 1968. november 12-én a NASA sajtótájékoztatón jelentette be, hogy engedélyezték az Apollo-8 útját. A holdkompot ballaszttal (LTA-B) helyettesítették. Három nappal később a TASZSZ bejelentette, hogy „első ízben tértek vissza élőlények a Hold térségéből”. Kiderült, hogy a Zond-5 fedélzetén teknősök, gyümölcslegyek, hernyók, növények és más biológiai objektumok is utaztak.

Az Apollo-8 végül 1968. december 21-én indult el a Hold felé. Karácsony este már a Hold körül keringő űrhajón, Frank Borman parancsnok a Teremtés Könyvéből idézett néhány mondatot. A $112 \mathrm{~km}$-es magasságban végrehajtott 10 keringéssel, lényegében megvalósult Verne Gyula álma. 


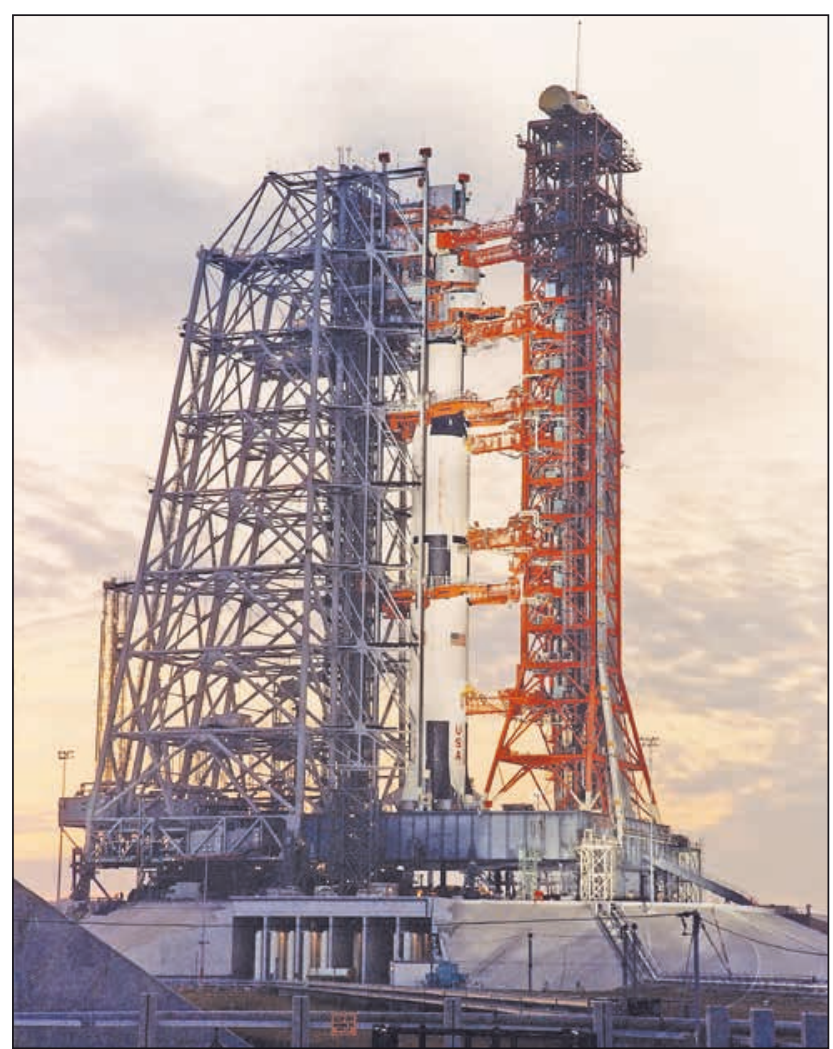

21. ábra. Starthelyen az Apollo-8 (Fotó: NASA)

Az Apollo-8 repülése tehát sikeresen lezajlott, és bár a történelem nem ismeri a „ha úgy történt volna" kategóriát, azért mégiscsak adódik a kérdés: ha az a bizonyos robbanás, amely az Apollo-13 műszaki egységében 1970 áprilisában bekövetkezett, szűk tizenhat hónappal korábban az Apollo-8 holdrepülésénél történik meg, vajon folytatódott volna az amerikai holdprogram? Három ürhajós biztos halála vajon megérte volna a kockázatot? James Lovell mindkét űrrepülésen ott volt a személyzet tagjaként, ezért ön-

22. ábra. Először jutott el ember a Hold közelébe (Fotó: NASA)

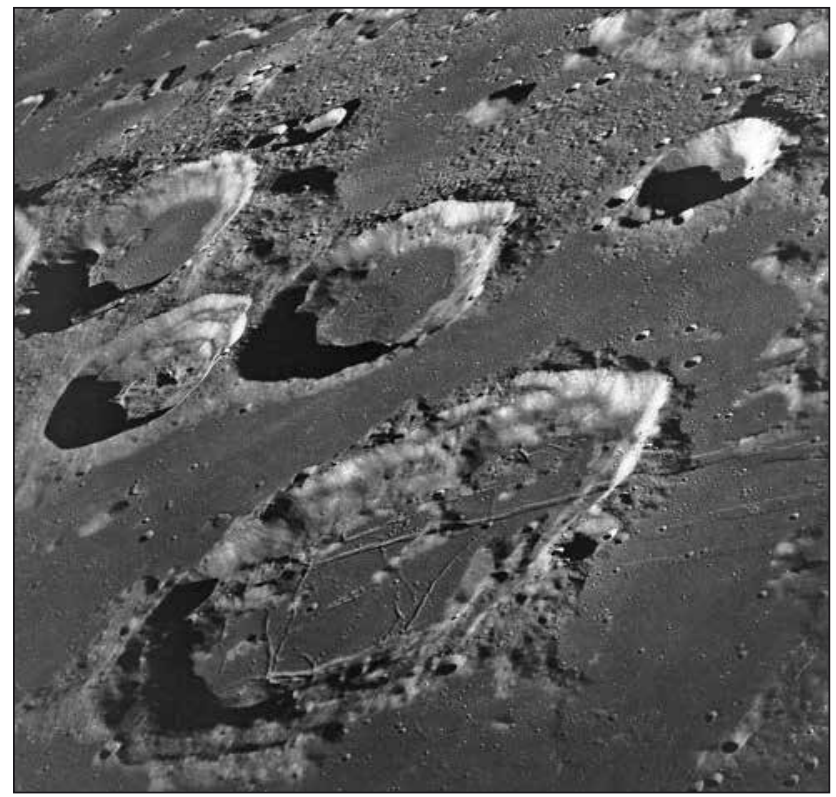

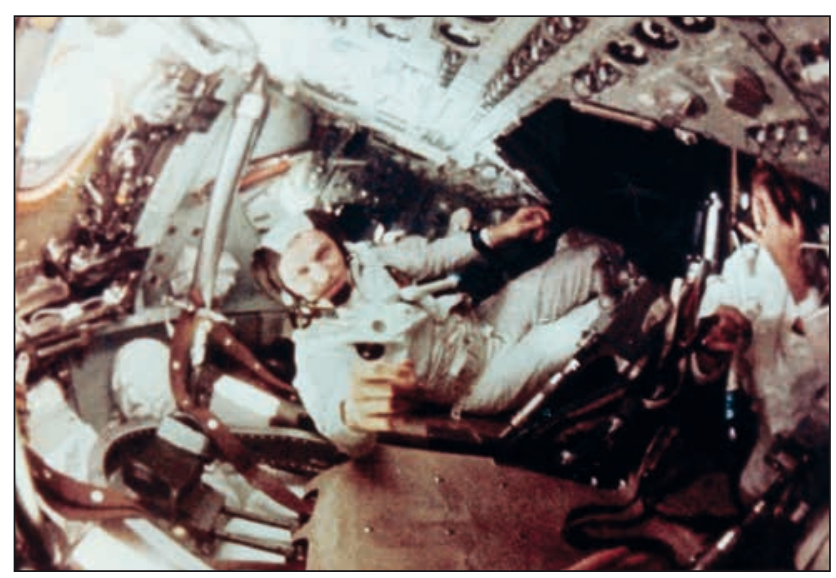

23. ábra. 1968. december 24-én, karácsony este a Hold körül keringő Apollo-8 fedélzetéröl, Frank Borman parancsnok a Teremtés Könyvéből idézve kívánt minden jót (Fotó: NASA)

ként adódik a kérdés: gondolt-e arra 1970-ben, hogy mi történt volna, ha az a robbanás az Apollo-8 múszaki egységét teszi használhatatlanná... De erre a kérdésre már sohasem kapjuk meg a választ.

1969 márciusában az Apollo-9 ürrepülése során az űrhajósok a parancsnoki fülkétől a holdkompon át a müszaki egységig minden részegységet kipróbáltak. Alapvető feladatuk volt, hogy a Holdra szállás minden mozzanatát, manőverét kipróbálják a Föld körüli pályán.

Az Apollo-10 volt a Holdra szállás főpróbája. Az űrhajósok 62 óra alatt 31 alkalommal kerülték meg a Holdat, és a leszállás kivételével végrehajtották a tényleges leszálláshoz szükséges összes manővert. A holdkomppal 15 km-re közelítették meg a Hold felszínét, és gyakorlatilag le is szállhattak volna. Az egyszerü földi halandó számára nehezen hihető, hogy az Apollo-10 űrhajósaiba beleivódott fegyelem és kötelesség felülírta a még oly erős kísértést is. 1969 májusában tehát minden készen állt arra, hogy az első ember a Holdra léphessen.

\section{Tervek És ÜRHAJósoK az Apollo-Programban}

1965-ben a NASA a következő menetrendet hozta nyilvánosságra az Apollo ürhajók felbocsátásával kapcsolaban:

1. Az első ember nélküli teszt, Saturn-IB-vel 1966-ban.

2. Az első pilótás berepülés, Saturn-IB-vel 1966-ban.

3. Az első ember nélküli teszt, Saturn-V-tel 1967-ben.

4. Az első pilótás berepülés Saturn-V-tel 1967-ben.

1966. március 21-én bejelentették az első, szeptember 29-én a második Apollo személyzetének összetételét és feladatát:

- Apollo-1/CSM-012 - Grissom, White, Chaffee (McDivitt, Scott, Schweickart) - az új ürhajó berepülése,

- Apollo-2/CSM-014 - Schirra, Eisele, Cunningham (Borman, Stafford, Collins) - a holdkomp kipróbálása.

A tapasztalt űrhajósok lettek a parancsnokok és a CM pilóták, az újoncok pedig a holdkomp pilóta státusát foglalhatták el. Ennek az volt az oka, hogy kezdetekben, az új ürhajó berepülésénél még nem volt az Apollo-szerelvényben holdkomp, ezért az újonc csak szimulációs gyakorlatokat hajthatott végre, de legalább tényleges ürrepülésben. Walter Cunningham önéletrajzában feltárta, hogy Schirra csak megbízott parancsnoka volt az Apollo-2-nek. Ugyanis Donald Slayton - akit 1962 márciusa óta eltiltottak az ürrepüléstől folyamatosan remélte, hogy megkapja az orvosi, repülési engedélyt. Azonban hiába számított rá, nem kapta meg. 
4. táblázat. Az Apollo-program repüléseinek típusa

\begin{tabular}{|c|l|l|l|}
\hline Típus & \multicolumn{1}{|c|}{ Feladat } & \multicolumn{1}{c|}{ Űrhajó } & \multicolumn{1}{c|}{ Ürrepülés } \\
\hline A & Ember nélküli teszt az Apollo űrhajóval. & $\begin{array}{l}\text { AS-201/CSM-009 } \\
\text { AS-202/CSM-011 } \\
\text { AS-203/CSM nincs } \\
\text { Apollo-4/CM-017 } \\
\text { Apollo-6/CM-020 }\end{array}$ & $\begin{array}{l}\text { 1966. február } \\
\text { 1966. augusztus } \\
\text { 1966. július } \\
\text { 1967. november } \\
\text { 1968. április }\end{array}$ \\
\hline B & Ember nélküli teszt a holdkomppal. & Apollo-5/LM-1 & 1968. január \\
\hline C & Pilótás berepülési teszt az Apollo ürhajóval. & $\begin{array}{l}\text { Apollo-7/CSM-101 } \\
\text { Apollo-8/CSM-103* }\end{array}$ & $\begin{array}{l}\text { 1968. október } \\
\text { 1968. december }\end{array}$ \\
\hline D & Pilótás berepülési teszt a holdkomppal. & Apollo-9/CSM-104/LM-3 & 1969. március \\
\hline E & Pilótás repülés nagy elliptikus pályán. & Apollo-13/CSM-109/LM-7 & 1970. április \\
\hline F & Holdra szálás nélküli, teljes próba. & Apollo-10/CSM-106/LM-4 & 1969. május \\
\hline G & Holdra szállás. & Apollo-11/CSM-107/LM-5 & 1969. július \\
\hline H & Megnövelt időtartamú holdi tartózkodás. & $\begin{array}{l}\text { Apollo-12/CSM-108/LM-6 } \\
\text { Apollo-14/CSM-110/LM-8 }\end{array}$ & $\begin{array}{l}\text { 1969. november } \\
\text { 1971. január-február }\end{array}$ \\
\hline J & Megnövelt időtartamú holdi tartózkodás, kiterjesztett & $\begin{array}{l}\text { Apollo-15/CSM-112/LM-10 } \\
\text { Apollo-16/CSM-113/LM-11 } \\
\text { Apollo-17/CSM-114/LM-12 }\end{array}$ & $\begin{array}{l}\text { 1971. július-augusztus } \\
\text { 1972. április } \\
\text { 1972. december }\end{array}$ \\
\hline
\end{tabular}

*Eredetileg „E” típusú volt, de a program felgyorsítása, azaz a szovjetek mindenáron való megelőzése érdekében megváltoztatták, és a „C prim” típusnevet kapta.

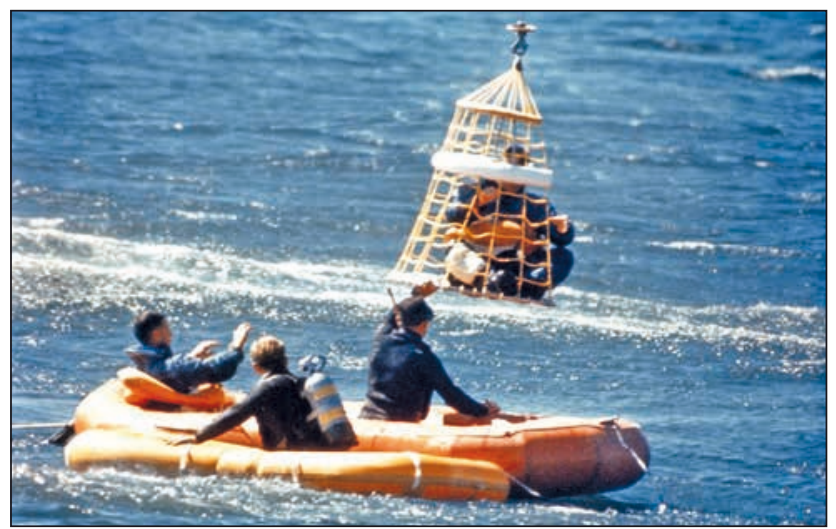

24. ábra. Így emelik a helikopter fedélzetére a visszatért ürhajósokat (Fotó: NASA)

A NASA-nál felmerült, hogy egy kettős repüléssel debütáljanak a programban, még a Gemini-12 startja (1966. november) előtt, de a CSM-012 földi vizsgálata a vártnál lassabban haladt. Nyilvánvalóvá vált, hogy az Apollo-1 nem indulhat el 1966-ban. Ezért elmaradt egy érdekes kísérlet a kéthetesre tervezett úton: egy kis centrifugában egy élő béka is helyet kapott volna a fedélzeten.

Az Apollo-2 megmaradt „unalmas” repülésnek, hiszen csak az Apollo-1 űrrepülését kellett volna megismételnie. Ebben a szakaszban azonban már erős össztűz alatt ált a NASA költségvetése, és november 17-én törölték is az Apollo-2/CSM-014/SA-205 űrrepülését, mint „indokolatlan ismétlését” az Apollo-1/CSM-012/SA-204-esnek. Azonban a Saturn-V sem készült el időre, de a holdkompot (LM), illetve az Apollo CSM-et lehetőleg együtt kellett kipróbálni. Ezért az a javaslat született, hogy két Saturn-IBvel oldják meg a feladatot, és a világürben kapcsolódjanak össze az űrjárművek. Az Apollo-2 - az Apollo-1 programjának ismétlése helyett - a kettős repülés főszerepét kapta meg. Az első - pilóta nélküli - holdkomp (LM-1) az SA206-ossal repült volna, míg az LM-2/SA-205-ös bonyolí- totta volna le az ürrandevút, az Apollo-3 CSM-101/SA208-assal. A tervezett módosítások miatt, 1966. december 22-ére az űrhajók személyzete is megváltozott:

- Apollo-1: Grissom, White, Chaffee (Schirra, Eisele, Cunningham) - „C”,

- Apollo-2: McDivitt, Scott, Schweickart, (Stafford, Young, Cernan) - „D”,

- Apollo-3: Borman, Collins, Anders (Conrad, Gordon, Williams) - „E”.

Hogy miért a McDivitt vezette személyzet kapta meg az új Apollo-2 repülést, arra csak egyetlen valószínű magyarázatot tudunk adni: Schirráék két újoncával szemben, náluk két,

\section{5. ábra. Az Apollo-8 ürkabinját az USS YORKTOWN} fedélzetére emelik (Fotó: NASA)

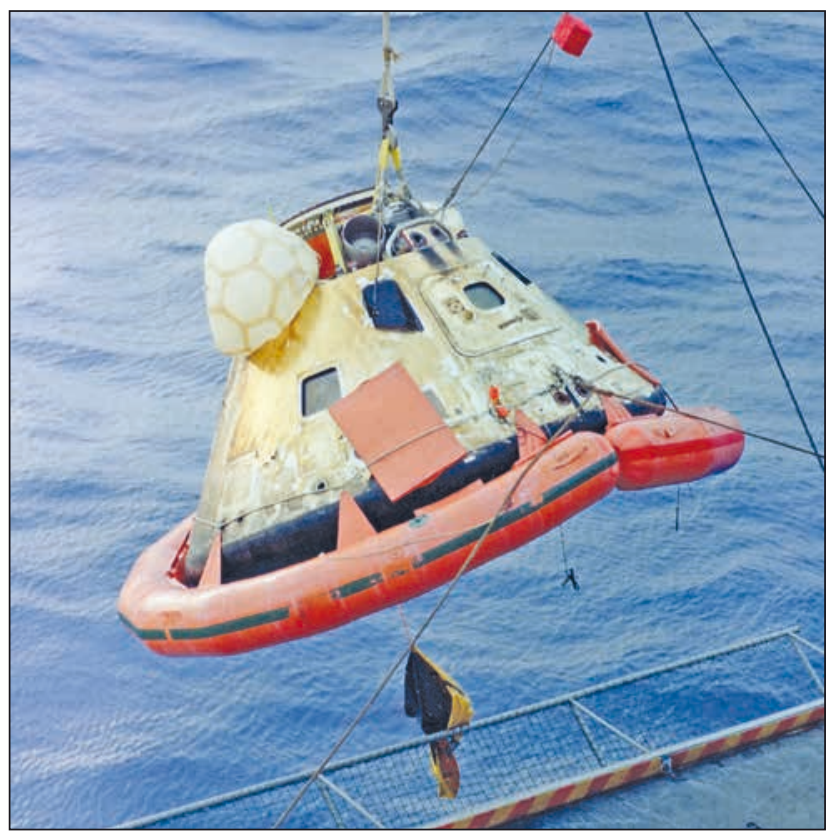


- Apollo-9/CSM-104 (LM-3): McDivitt, Scott, Schweickart (Conrad, Gordon, Bean).

Bormanék holdkompja a fejlesztési nehézségek és a lassan folyó vizsgálatok miatt, 1969 tavaszáig még nem állhatott startra készen. Az LM-2 - bár elvileg előbb elkészülhetett - a feladathoz túlsúlyosnak bizonyult, és szintén késésben volt.

1968 decemberében, a mútét után felépült Michael Collins visszatért az Armstrong vezette személyzetbe. A Donald Slayton vezette houstoni Astronauts Office 1969. január 6-án jelentette be, hogy valószínüleg ők fognak elsőként leszállni a Holdon. A NASA ezzel - elsősorban személyes okokból - óriási változásokat indított el ürhajós keretében.

Walter Schirra 45 éves volt az Apollo-7 felkészülése idején, és az egyik legtapasztaltabb ürhajós lévén, komoly esélye volt az első Holdra szállás parancsnoki pozíciójára. Slayton azonban nem támogatta Schirrát, aki júliusban hátat is fordított a NASA-nak, és a privát üzleti szférában helyezkedett el. Cunningham és Eisele sem jutott el soha többé a világürbe, bár Eisele-nek még, az Apollo-10 tartalék személyzetének tagjaként, komoly esélye volt, hogy az Apollo-13 CM pilótájaként eljusson a Hold közelébe. (Az „ürvetésforgó" elve szerint a tartalék személyzet három repüléssel később alkotta az első számú személyzetet).

- Apollo-13: Cooper, Eisele, Mitchell,

- Apollo-14: Lovell, Anders, Haise.

1969. május 7-én a NASA bejelentette, hogy az 1963ban belsőfül-gyulladás problémák miatt az ürhajós keretből kimaradt Alan Shepard - az első amerikai ürhajós visszatért az aktív állományba. Reaktiválásának Cooper, Eisele és Anders lett a nagy vesztese, helyükre Shepard, Mattingly és Roosa került.

Augusztus 7-ére így alakult át a két személyzet:

- Apollo-13: Lovell, Mattingly, Haise,

- Apollo-14: Shepard, Roosa, Mitchell.

A további repülések személyzeti összetétele így alakult (beleértve a később törölteket is):

- Apollo-15: Scott, Worden, Irwin (Gordon, Brand, Schmitt),

- Apollo-16: Young, Mattingly, Duke (Haise, Roosa, Mitchell),

- Apollo-17: Cernan, Evans, Schmitt (Scott, Worden, Irwin),

- Apollo-18: Gordon, Brand, Schmitt,

- Apollo-19: Haise, Pogue, Carr,

- Apollo-20: Roosa, Lind, Lousma.

1970. január 4-én az Apollo-20, majd március 26-án az Apollo-18 és -19 utazását, pénzügyi okok miatt véglegesen törölték. A megmaradt úreszközöket később - részben a Skylab, illetve az ASTP programokban használták fel.

$$
\text { (Folytatjuk) }
$$

A cikkhez tartozó forrásokat a következő résznél közöljük. (Szerk.)

- Apollo-8: SA-503/CSM-103/LM-2, McDivitt személyzet,

- Apollo-9: SA-504/CSM-104/LM-3, Borman személyzet.

Tény, hogy az Apollo-7 be is váltotta a hozzáfüzött reményeket, de csak kissé javított a helyzeten. Ennek személyi és tárgyi oka volt.

Még az Apollo-7 repülése előtt, 1968. július 12-én Michael Collins nyakán egy csontkinövést diagnosztizáltak, ami - a gerinchez nyomódást megelőzve - azonnali műtétet igényelt. Természetesen a személyzetek összetétele azonnal megváltozott:

- Apollo-7/CSM-101: Schirra, Eisele, Cunningham (Stafford, Young, Cernan),

- Apollo-8/CSM-103: Borman, Lovell, Anders (Armstrong, Aldrin, Haise),

\section{Az Apollo programmal kapcsolatos röviditések}

AS - Apollo-Saturn.

ASTP - Apollo Soyuz Test Project - Apollo Szojuz Vizsgálati Terv.

CM - Command Module - parancsnoki egység vagy modul, Apollo ürkabin.

CSM - Command (and) Service Module - parancsnoki (és) műszaki egység vagy modul, Apollo űrhajó.

LM - Lunar Module - holdkomp.

LTA - Lunar Test Article - teszt holdkomp.

SA - Saturn-Apollo

S-IVB - Saturn-IB második vagy a Saturn-V harmadik fokozata. 